\title{
Metformin/Glimepiride and Metformin/Glibenclamide, Which is Better?: A Systematic Review and Meta-Analysis
}

\author{
Yedy Purwandi Sukmawan \\ Department of Clinical Pharmacy and Pharmacology, \\ Institute of Health Science of Bakti Tunas Husada Tasikmalaya, West Java, Indonesia
}

\begin{abstract}
Background: Type 2 diabetes mellitus (DM) is associated with the microvascular and macrovascular complication. Metformin and sulphonylurea (glimepiride and glibenclamide) combination is widely used for the treatment of type $2 \mathrm{DM}$. This study aimed to examine the difference of Metformin/Glimepiride and Metformin/Glibenclamide administrations in reducing HbA1C among type 2 DM patients.

Subjects and Method: This was a systematic review and meta-analysis according to PRISMA guideline with PICO construction using MeSH and text-word. 214 article were identified from PubMed, Cochrane, other source databases. Two articles with 183 type 2 DM patients were selected for this study.

Results: No significant difference on $\mathrm{HbA1C}$ level, fasting plasma glucose, and hypoglycemia adverse events between glimepiride/metformin and glibenclamide/metformin combinations. However, glimepiride/metformin combination demonstrated lower $\mathrm{HbA1C} \mathrm{(-0.11;95 \%} \mathrm{CI=-0.41} \mathrm{to}$ $0.18 ; \mathrm{p}=0.450)$ and lower hypoglycemia adverse events $(\mathrm{OR}=0.52 ; 95 \% \mathrm{CI}=-1.02$ to $3.05 ; \mathrm{p}=$ 0.450), while glibenclamide/metformin combination demonstrated lower fasting plasma glucose concentration (1.01; 95\% CI= -1.02 to $3.05 ; \mathrm{p}=0.450)$.
\end{abstract}

Conclusion: Glimepiride/metformin combination is preferable in $\mathrm{HbA1C}$ lowering and hypoglycemia risk than glibenclamide/metformin combination.

Keywords: Glimepiride-metformin, Glibenclamide-metformin, type 2 diabetes mellitus

\section{Correspondence}

Yedy Purwandi Sukmawan. Department of Clinical Pharmacy and Pharmacology, Institute of Health Science of Bakti Tunas Husada Tasikmalaya, West Java, Indonesia. Email: yedipur@gmail.com

\section{BACKGROUND}

The disease burden related to diabetes is high and global prevalence in 2035 is expected to rise to 592 million people in the whole world (Forouhi dan Wareham, 2014). $\mathrm{HbA} 1 \mathrm{C}$ and fasting plasma glucose concentration maintaining in the target range are important to prevent microvascular (retinopathy, nephropathy, and neuropathy) and macrovascular (cardiovascular disease) complication (Chawla et al., 2016; Juarez et al., 2014). Metformin, glimepiride, and glibenclamide are an example of type 2 diabetes mellitus drugs. Sulfonylureabiguanide combination is common to use and recommended for the treatment of type $2 \mathrm{DM}$ in dual therapy (Aamir et al., 2015; Ridle et al, 2018). A Comprehensive review of comparison of the combinations is still unknown. The objective of the study is to compare efficacy ( $\mathrm{HbA1C}$ and fasting plasma glucose) and Adverse event (Hypoglycemia).

\section{SUBJECTS AND METHOD}

\section{Study design}

The systematic review and meta-analysis are according to the Preferred Reporting Items for Systematic Reviews and MetaAnalyses guidelines (PRISMA) (Moher et 
al, 2009). The search strategy includes articles indexed in PubMed, Cochrane database and other resources (worldwide website) with study selection using Problem, Intervention, and Comparison (PICO constructed) with Medical Subject Heading (MeSH) and keywords "Diabetes Mellitus, Type 2", "Metformin", "Glyburide", "Glimepiride", "Glibenclamide".

The studies need to fulfill the following inclusion criteria: (1) Glimepiride/ Metformin as intervention drugs, Glibenclamide/Metformin as a comparator (2) Type 2 Diabetes Mellitus patients, (3) randomized controlled trials study design, (4) HbA1C, Fasting Plasma Glucose as an outcome, Hypoglycemia as an adverse event (5) original articles, and (6) study published in the English language publications. The data were extracted from each publication involved source of study (year), study design, sample size (number of subjects), duration of treatment, outcome ( $\mathrm{HbA1C}$, Fasting Plasma Glucose, Hypoglycemia adverse event), and article quality.

\section{Data analysis}

The Data were analyzed using RevMan 5.3. Data were expressed as standard mean difference ( $\mathrm{HbA} 1 \mathrm{C}$ and Fasting Plasma Glucose) or Odds Ratio (Hypoglycemia adverse event) using a 95\% confidence interval. The $\mathrm{P}$ value $<0.05$ was defined as statistically significant for all outcomes.

\section{RESULTS}

The Initial search identified 214 articles, which 123 articles from Cochrane, 90 articles from Pubmed, and 1 article from other sources (Figure 1). 210 articles are excluded unlikely to be relevant based on the title and abstract screening. Four articles are included for the full review article.

Two article is excluded after the full review due to the 1 ). Glibenclamide is not a comparator in combination with metformin, 2). Glimepiride is not an interventions drugs in combination metformin. Two articles are included for qualitative and quantitative analysis. The article's method is randomized controlled trials ( 1 article are open-label; 1 article double-blind and multicenter) and 183 patients are involved in the study with 3 patients are not completed the study.

\section{HbA1C}

Glimepiride/metformin combination did not show significant difference of $\mathrm{HbA1C}$ reduction compared with glibenclamide/ metformin combination $(-0.11 ; 95 \% \mathrm{CI}=-$ 0.41 to $0.18 ; p=0.45)$. Moreover, not found statistical heterogeneity in this trials $(\mathrm{p}=$ o.43). However, glimepiride/metformin combination showed lower HbA1C concentration than glibenclamide/metformin combination.

\section{Fasting Plasma Glucose}

Fasting plasma glucose demonstrated the same results with $\mathrm{HbA1C}$ parameter. No significant difference were observed between glimepiride/metformin and glibenclamide/ metformin combination in fasting plasma glucose concentration (1.01; 95\% $\mathrm{CI}=-1.02$ to $3.05 ; \mathrm{p}=0.45$ ). However, glibenclamide/ metformin combination showed lower fasting plasma glucose concentration than glimepiride/metformin combination.

\section{Hypoglycemia Adverse Events}

Hypoglycemia is a serious problem in type 2 diabetes mellitus medication. No significant difference were observed of hypoglycemia adverse events between glimepiride/ metformin and glibenclamide/metformin group $(\mathrm{OR}=0.52 ; 95 \% \mathrm{CI}=-1.02$ to 3.05 ; $\mathrm{p}=0.450$ ). However, glimepiride/ metformin combination showed lower hypoglycemia adverse events compared with glibenclamide/metformin combinations. 
Sukmawan et al./ Metformin/Glimepiride and Metformin/Glibenclamide

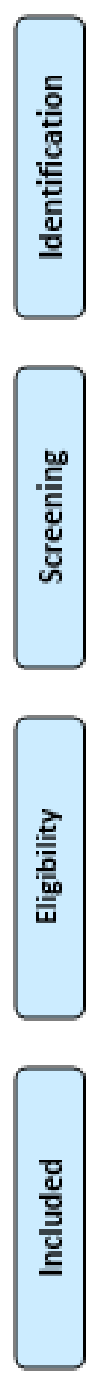

Records identified through Pubme and Cochrane database ( $n=213$ )

Additional records identified through other sources $(n=1)$

Article excluded unlikely to be relevant based on title and abstract $(n=210)$

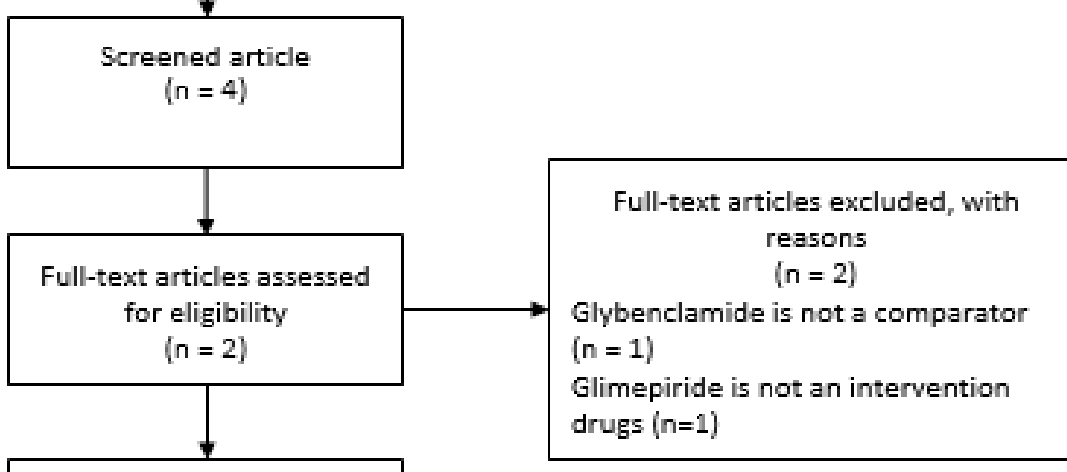

Studies included in qualitative synthesis ( $n=2$ )

Studies included in quantitative synthesis (meta-analysis) ( $n=2$ )

Figure 1. Article Selection Process 
Table 1. Study Characteristic

\begin{tabular}{|c|c|c|c|c|c|c|c|c|c|c|}
\hline \multirow{2}{*}{$\begin{array}{l}\text { Study } \\
\text { (year) }\end{array}$} & \multirow{2}{*}{$\begin{array}{l}\text { Study } \\
\text { Design }\end{array}$} & \multirow{2}{*}{$\begin{array}{c}\text { Number } \\
\text { of Subject } \\
\text { (Com- } \\
\text { pleted) }\end{array}$} & \multirow{2}{*}{$\begin{array}{l}\text { Duration } \\
\text { of Treat- } \\
\text { ment }\end{array}$} & \multicolumn{2}{|c|}{$\begin{array}{c}\text { HbA1C } \\
\text { Reduction }\end{array}$} & \multicolumn{2}{|c|}{$\begin{array}{c}\text { Fasting Plasma } \\
\text { Glucose } \\
\text { Reduction }\end{array}$} & \multicolumn{2}{|c|}{$\begin{array}{c}\text { Hypoglycemia } \\
\text { Events }\end{array}$} & \multirow[t]{2}{*}{ Article Quality } \\
\hline & & & & $\begin{array}{l}\text { Glim } \\
\text { / Met }\end{array}$ & $\begin{array}{c}\text { Glyb/ } \\
\text { Met }\end{array}$ & $\underset{\text { Met }}{\text { Glim/ }}$ & $\begin{array}{c}\text { Glyb/ } \\
\text { Met }\end{array}$ & $\begin{array}{c}\text { Glim/ } \\
\text { Met }\end{array}$ & $\begin{array}{c}\text { Glyb/ } \\
\text { Met }\end{array}$ & \\
\hline $\begin{array}{l}\text { Shimpi } \\
\text { Et al, } \\
2009\end{array}$ & $\begin{array}{l}\text { RCT (open } \\
\text { label) }\end{array}$ & $31(28)$ & 12 week & $\begin{array}{l}1.376 \\
\pm 0.27\end{array}$ & $\begin{array}{l}1.227 \\
\pm \\
0.48\end{array}$ & $\begin{array}{c}54.59 \pm \\
10.84\end{array}$ & $\begin{array}{c}92.09 \pm \\
24.25\end{array}$ & 3 & 3 & $\begin{array}{l}\text { Randomization (Well } \\
\text { Report) } \\
\text { Double Blind (No) } \\
\text { Allocation Concealment } \\
\text { (Unclear) } \\
\text { Withdrawal and Dropout } \\
\text { (Well Report) }\end{array}$ \\
\hline $\begin{array}{l}\text { Gonzal } \\
\text { ez- } \\
\text { Ortiza } \\
\text { et al, } \\
2008\end{array}$ & $\begin{array}{l}\text { RCT (Rando- } \\
\text { mized, Dou- } \\
\text { ble blind and } \\
\text { multicenter) }\end{array}$ & $15^{2}(152)$ & 12 month & $\begin{array}{c}2.1 \pm \\
1.6\end{array}$ & $\begin{array}{c}2.0 \pm \\
1.5\end{array}$ & $\begin{array}{c}72.1 \pm \\
73.9\end{array}$ & $\begin{array}{c}73.9 \pm \\
66.7\end{array}$ & 13 & 22 & $\begin{array}{l}\text { Randomization (Well } \\
\text { Report) } \\
\text { Double Blind (yes) } \\
\text { Allocation Concealment } \\
\text { (Well Report) } \\
\text { Withdrawal and Dropout } \\
\text { (Well Report) }\end{array}$ \\
\hline
\end{tabular}

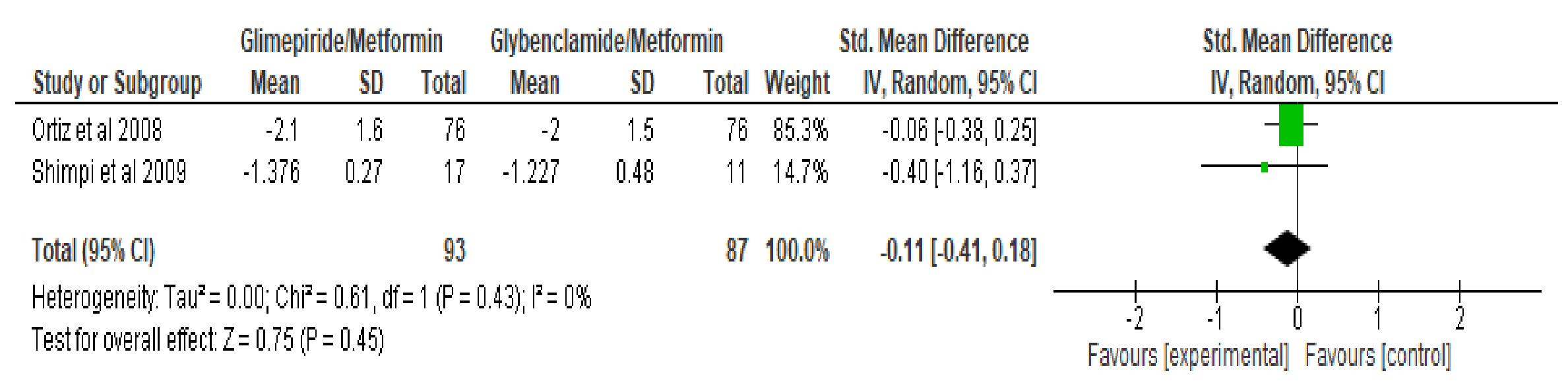

Figure 2. Difference of $\mathrm{HbA1C}$ reduction 


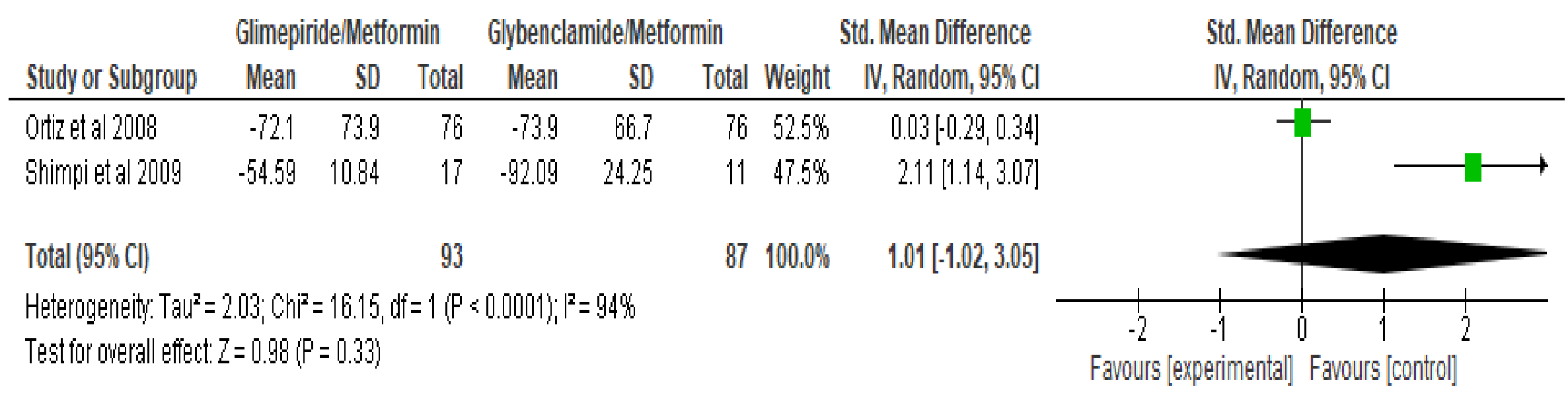

Figure 3. Fasting Plasma Glucose

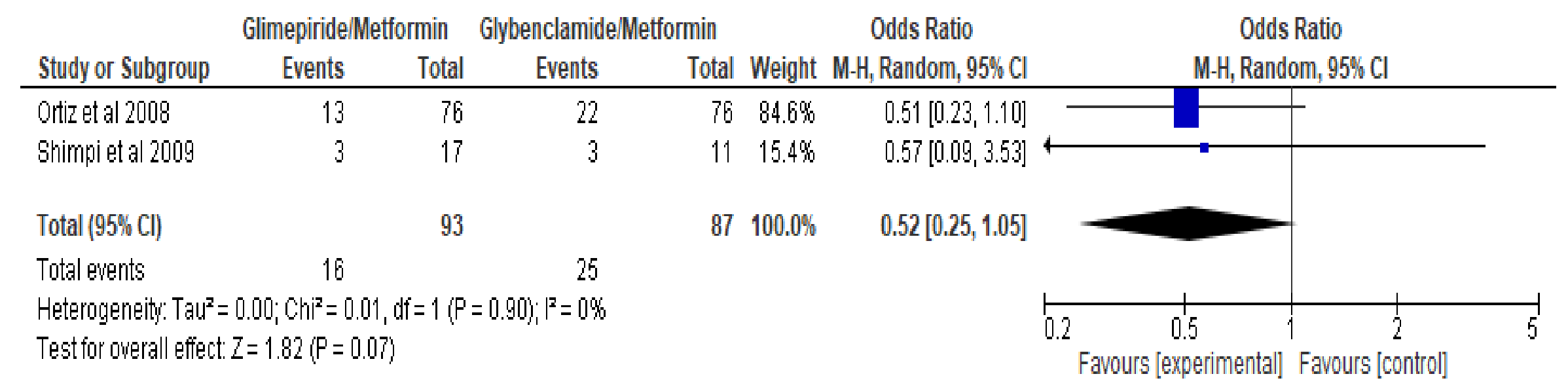

Figure 4. Hypoglycemia Adverse Events 


\section{DISCUSSION}

Metformin is the first line of choice for Type 2 Diabetes Mellitus, if does not achieve the $\mathrm{HbA1C}$ goal over 3 months, add an additional of other antihyperglycemics (American Diabetes Association, 2018). Glibenclamide and Glimepiride widely used as a second line therapy in combination with metformin (Rani et al., 2014). HbA1C is an important parameter to achieve in type 2 diabetes mellitus patients and associated with all-cause mortality, while hypoglycemia is a common adverse reaction and life-threatening associated (American Diabetes Association, 2018; Arnold and Wang, 2014). Studies have shown that incidence rates of hypoglycemia in sulphonylurea users range from $0.2-1.8$ per 100 people (without renal impairment) (Van Dalem, 2016). Therefore, achieved HbA1C goal and minimize hypoglycemia risk is an important goal in type 2 diabetes mellitus medications.

No significant difference is observed on HbA1C, fasting plasma glucose, and hypoglycemia adverse events between glimepiride/metformin and glibenclamide/ metformin combination. However, glimepiride/ metformin combination demonstrated lower HbA1C and hypoglycemia adverse events, while glibenclamide/ metformin combination demonstrated lower fasting plasma glucose concentration.

Glimepiride and glibenclamide are in the same class of sulphonylurea group. However, there is difference engagement for the mechanism of action between glimepiride and glibenclamide. Glimepiride molecular study demonstrated interaction with lipid rafts, DIGs, at the plasma membrane of adipose and muscle cells induces the insulin-mimetic activity via the activation of a glycosylphosphatidylinositol-specific phospholipase, redistribution of signaling components and positive cross-talk downstream to the insulin signaling cascade and interference with additional molecular mechanisms in extrapancreatic cells (e.g. regulation of adipocytokine release from and differentiation of adipocytes), relying on or independent of SUR and DIGs, contributes to the insulin-sensitizing activity of glimepiride (Muller, 2005).The molecular characterization between glimepiride and glibenclamide showed kinetic, steady state and competitive binding of glimepiride is $3^{-}$to 4 -fold lower binding affinity to isolated beta-cell membranes and intact beta-cells compared to glibenclamide, while for photoaffinity labelling of beta-cells membrane protein showed $65^{-}$ kDA binding protein for glimepiride and 140-kDA binding protein for glibenclamide. Moreover, glimepiride showed 3- to 4-fold lower depolarization activity than glibenclamide (Kramer et al., 1996; Hu et al.,2000). The low risk hypoglycemia adverse events may be due to the lowest affinity, binding and depolarization activity of glimepiride than glibenclamide.

Based on the results of this study, it can conclude that glimepiride/metformin combination is preferable in $\mathrm{HbA1C}$ lowering and hypoglycemia risk than glibenclamide/metformin combination.

\section{ACKNOWLEDGEMENTS}

Author thanks to Mrs Ai Teni Alfianti.,S.Pd for the encourage.

\section{FUNDING AND SPONSORSHIP}

The research received no specific grant from any funding agency in the public, commercial or not for profit sectors.

\section{CONFLICT OF INTEREST}

Author declare that there is no conflict of interest regarding the publication of this paper. 


\section{REFERENCE}

Aamir SKAH, Raza A, Das AK, Khan AKA, Shrestha D, Qureshi F, et al. (2015). Place of sulfonylureas in the management of type 2 diabetes mellitus in South Asia: A consensus statement. Indian J Endocrinol Metab. 19(5): 577-96. https://dx.doi.org/10.4103\%2F2230-8210.163171

American Diabetes Association (2018). Standards of medical care in diabetes-2018 abridged for primary care providers. Clinical Diabetes; 36 (1): 14-37. Doi: 10.2337/cd17-0119.

Arnold LW, Wang Z (2014). The HbA1c and all-cause mortality relationship in patients with type 2 diabetes is $\mathrm{J}$ shaped: a meta-analysis of observational studies. Rev Diabet Stud. 11(2): 138-52. doi: 10.1900/RDS.2014.11.138.

Chawla A, Chawla R, Jaggi S (2016). Microvasular and macrovascular complications in diabetes mellitus: Distinct or continuum?. Indian $\mathrm{J}$ Endocrinol Metab. 20(4): 546-51. https://dx.doi.org/10.4103\%2F2230-8210.183480.

Forouhi NG, Wareham NJ (2014). Epidemiology of diabetes. Medicine (Abingdon). 42(12): 698-702. https://dx.doi.org/10.1016\%2Fj.mpmed.2014.09.007 .

González-Ortiza M, Guerrero-Romeroc JF, Violante-Ortizd R, Wacher-Rodartee $\mathrm{N}$, -Abundisa EM, Aguilar-Salinasf C, et al. (2009). Efficacy of glimepiride/ metformin combination versus glibenclamide/ metformin in patients with uncontrolled type 2 diabetes mellitus. Journal of Diabetes and Its Complications;23:376-379. doi: 10.1016/j.jdiacomp.2008.09.002.

Hu S, Wang S, Fanelli B, Bell PA, Dunning BE, Geisse $S$ et al (2000). Pancreatic beta-cell K (ATP) channel activity and membrane-binding studies with nateglinide: A comparison with sulfonylureas and repaglinide. J Pharmacol Exp Ther. 293(2):444-52.

Juarez DT, Ma C, Kumasaka A, Shimada R, Davis J (2014). Failure to reach target glycated a1c levels among patients with diabetes who are adherent to their antidiabetic medication. Popul Health Manag; 17(4): 218-23.

Kramer W, Müller G, Geisen K (1996). Characterization of the molecular mode of action of the sulfonylurea, glimepiride, at beta-cells. Horm Metab Res. 28(9):464-8.

Moher D, Liberati A, Tetzlaff J, Altman DG (2009). Preferred reporting items for systematic reviews and meta-analyses: the PRISMA statement. PLoS Med. 6(7):e1000097. doi: 10.1371/journal.pmed.1000097.

Muller G (2005). The mode of action of the antidiabetic drug glimepiride-beyond insulin secretion. current medicinal chemistry. Immunology, Endocrine \& Metabolic Agents. 5(6): 499-518. doi: 10.2174/156801305774962123.

Rani M, Yadav S, Gupta P, Pandey S, Choudhary S (2014). A study comparing the effect of glimepiride and glibenclamide on glycosylated haemoglobin (Hba1c) in type II diabetes mellitus patients. IJMSPH. 3(1): 35-7. https://dx.doi.org/10.5455/ijmsph.2013.2o0920134.

Ridle MC, Bakris G, Blonde L, Boulton AJM, D'Alesio D, De Groot M, et al. (2018). Professional practice committee: Standards of medical care in diabetes - 2018. Diabetes Care. 41(1): S3. https://doi.org/10.2337/dc18-Sppco1

Shimpi RD, Patil PH, Kuchake VG, Ingle PV, Surana SJ, Dighore PN (2009). Comparison of effect of metformin in combination with glimepiride and 
Indonesian Journal of Medicine (2019), 4(3): 211-218

https://doi.org/10.26911/theijmed.2019.04.03.03

glibenclamide on glycaemic control in patient with type 2 diabetes mellitus. Int.J. PharmTech Res; 1(1): 50-61.

Van Dalem J, Brouwers MCGJ, Stehouwer CDA, Leufkens HGM, Driessen JHM, De Fries, Burden AM (2016). Risk of hypoglycemia in users of sulphonylureas compared with metforminin relation to renal function and metabolite group: population based cohort study. BMJ; 354; i3625. https://doi.org/10.1136/bmj.i3625 